Research Article

\title{
Numerical Simulation and Optimization Design of End-Suspended Pile Support for Soil-Rock Composite Foundation Pit
}

\author{
Qingchao Xu, ${ }^{1}$ Zhenhao Bao $\mathbb{D}^{2},{ }^{2} \mathrm{Tu} \mathrm{Lu}^{2}{ }^{2}$ Huarui Gao, ${ }^{1}$ and Jiakang Song ${ }^{1}$ \\ ${ }^{1}$ Shandong Hi-Speed Construction Management Group Co., Ltd., 260014 Shandong, Jinan, China \\ ${ }^{2}$ School of Civil Engineering, Shandong University, 250061 Shandong, Jinan, China \\ Correspondence should be addressed to Zhenhao Bao; bzh1998@mail.sdu.edu.cn
}

Received 17 January 2021; Revised 7 June 2021; Accepted 22 June 2021; Published 2 July 2021

Academic Editor: Giovanni Garcea

Copyright (C) 2021 Qingchao Xu et al. This is an open access article distributed under the Creative Commons Attribution License, which permits unrestricted use, distribution, and reproduction in any medium, provided the original work is properly cited.

In order to design the soil-rock combination foundation pit more safely and effectively, this paper presents the investigations of the mechanical and deformational characteristics of end-suspended piles supporting the structures in Jinan CBD area. Based on the measured data, a finite element model was established through the two-dimensional numerical simulation method to study the deformational characteristics of the end-suspended piles, and the influences of the depth of socketed rock, the width of rock shoulder, and the prestress of anchor cables on the deformations and mechanical property of end-suspended piles were discussed. Some optimization methods are proposed based on these analyses. Results show the following: (1) Rock-socketed depths have boundary effect on end-suspended piles. Under the given geological conditions, the reasonable socketed ratio is within $0.158 \sim 0.200$. (2) The anchor cable prestress can effectively slow down the ground settlement, the force, and deformation of the pile body and can be set to $1 P \sim 1.25 P$ under the conditions of the site. (3) Rock-shoulder width has little influence on the ground settlement and horizontal displacement of piles. The reserved width of rock shoulder is suggested to be selected in the range of $1.0 \mathrm{~m} \sim 1.5 \mathrm{~m}$.

\section{Introduction}

Subway is gradually becoming an important way to improve urban traffic, and the deep foundation pit engineering of subway station plays an important role in subway construction. There are a lot of intrusive magmatic rocks in Jinan area, resulting in the fact that the thickness of soil layer is generally less than $30 \mathrm{~m}$ [1]. Therefore, there are a large number of soil rock composite foundation pits in Jinan area; that is, the upper part of the foundation pit is soil layer and the lower part is rock layer. The supporting structure of endsuspended pile is a kind of supporting structure which is widely used in soil rock composite foundation pit at present.

Many domestic scholars have carried out research on the stress, deformation, and optimal design of the supporting structure of end-suspended piles. Liu and Li [2] analyzed the mechanical and deformation characteristics of the supporting structure of the end-suspended pile in the soil rock composite foundation pit by numerical modeling. The results show that the supporting effect of the endsuspended pile in the soil rock composite foundation pit is good, but the rock blasting construction has a great adverse effect on the stress and deformation of the microsteel pipe pile. Liu et al. [3] analyzed the stress and deformation of end-suspended pile in soil rock composite foundation pit by numerical simulation and mainly studied the influence of rock-socketed depth and rock-shoulder width on the stress and deformation of end-suspended pile. The results show that when the width of rock shoulder and the depth of rock socket reach a certain value, the increase of rock shoulder has little effect on the pile deformation. Wu et al. [4] analyzed the influence of soil rock elastic modulus ratio, rock-socketed depth, and rock-shoulder width on pile stress and deformation through finite element simulation. 
The results show that, with the excavation of foundation pit, the horizontal displacement of pile increases and the deformation position moves down; when the excavation reaches the soil rock interface, the shear force and bending moment of the pile body are the maximum; the rocksocketed depth is $1.5 \mathrm{~m}$ and the rock-shoulder width is $1.5-2.0 \mathrm{~m}$. Taking a station of Qingdao Metro as the research background, Abbott et al. [5] established a plane model through PLAXIS 2D to analyze the deformation characteristics of the soil rock dual element foundation pit supported by the end-suspended pile. The research shows that the reciprocal first row of prestressed anchor cables set in the length range of the end-suspended pile play a significant role in controlling the horizontal displacement of the pile foot during the excavation of the foundation pit.

To sum up, these studies are mainly aimed at Qingdao, Dalian, and other areas, and the conclusions are of certain significance for the stress and deformation characteristics of end-suspended pile support. However, there is still a lack of research on the supporting characteristics of the end-suspended pile in Jinan area [6-8], and the research on the bearing capacity of the rock-shoulder part of the end-suspended pile is not thorough enough, which is difficult to guide the engineering application. Based on PLAXIS 2D finite element numerical simulation of foundation pit deformation, this paper studies the stress and deformation characteristics of end-suspended pile support in Jinan area and analyzes the influence of anchor cable prestress, rocksocketed depth, rock-shoulder width, and other factors on foundation pit deformation and support structure stress, so as to put forward corresponding optimization design suggestions.

\section{Deformation Characteristics of Typical Section of the Foundation Pit Supported by End-Suspended Piles}

2.1. Project Overview. Underground rail transit project is an important part of the development and utilization of underground space in Jinan, including five stations and four sections. This paper mainly analyzes the South Industrial Road station. The basic information of subway station is shown in Table 1. According to the stratum conditions revealed in the depth range of engineering geological survey, the Quaternary stratum is mainly composed of silty clay, clay, silty clay with gravel, gravel, and cemented conglomerate, and loess is partially exposed. Ordovician limestone is underlain in Quaternary strata, and marl is exposed locally.

\subsection{Establishment of the Finite Element Model. According to} the foundation pit at the east side of axis 1-3 of Gongye South Road station, the numerical model of the foundation pit supported by end-suspended piles is established, as shown in Figure 1. The excavation depth of the foundation pit is $23.5 \mathrm{~m}$. In order to ensure the accuracy of the results, the width of the model size is 2-3 times the excavation depth of the foundation pit, and the depth is about 2 times the excavation depth of the foundation pit. Therefore, the model size is $64 \mathrm{~m} \times 47 \mathrm{~m}$. See Table 2 for specific geotechnical parameters, Table 3 for support structure parameters, Table 4 for prestressed anchor cable parameters, and Table 5 for specific excavation conditions.

2.3. Surface Subsidence. Five ground settlement monitoring points are set in the section, and the distance from the edge of the foundation pit is $1 \mathrm{~m}, 4 \mathrm{~m}, 9 \mathrm{~m}, 14 \mathrm{~m}$, and $24 \mathrm{~m}$, respectively. Figure 2 shows the ground settlement values and numerical simulation results of the monitoring points under various working conditions. It can be seen that the ground settlement outside the foundation pit presents a typical "spoon type." With the increase of the distance to the edge of the foundation pit, the ground settlement value increases rapidly and then decreases and reaches the maximum at about $4 \mathrm{~m}$ away from the edge of the foundation pit. If the limit value $H$ of surface subsidence influence range is $-0.5 \mathrm{~mm}$, the corresponding surface subsidence influence range of each working condition is about $0.49 \mathrm{H}, 0.60 \mathrm{H}$, $0.70 \mathrm{H}$, and $0.81 \mathrm{H}$, respectively. It can be seen that the influence range of surface subsidence increases with the increase of excavation depth.

Figure 3 shows the change of the maximum ground settlement with the excavation depth. It can be seen that the maximum ground settlement increases with the increase of the excavation depth. When the excavation reaches $16.0 \mathrm{~m}$, the ground settlement has completed $87.82 \%$ of the maximum settlement value, and then the increase rate becomes smaller. The reason is that the self-stability of the rock is good, and it shows that most of the ground settlement outside the combined foundation pit is produced in the soil excavation stage; the difference between the numerical simulation results and the measured values is $0.09 \mathrm{~mm}$, $0.24 \mathrm{~mm}, 0.42 \mathrm{~mm}$, and $0.21 \mathrm{~mm}$, respectively, which shows that the numerical model can better reflect the deformation characteristics of the ground outside the pit.

2.4. Stress and Deformation Characteristics of the Pile. The horizontal displacement of the pile is shown in Figure 4. It can be seen that the overall shape of the horizontal displacement curve of the pile from the numerical simulation results under each working condition is similar to the measured results, showing an obvious parabolic shape. The main reason is that the soil pressure on the pile top is small, and the prestressed anchor cable at the top limits the horizontal displacement of the pile, while the part near the rock shoulder at the bottom is constrained by the rock shoulder. Similarly, the horizontal displacement is small.

The variation trend of maximum horizontal displacement of pile with foundation pit excavation is shown in Figure 5. The horizontal displacement of the pile increases rapidly in the soil excavation stage, and the horizontal displacement has completed $93.24 \%$ in this stage, which indicates that the horizontal displacement of the end-suspended pile also mostly occurs in the soil excavation stage. 
TABLE 1: General situation of the subway station foundation pit.

\begin{tabular}{lccccc}
\hline Station & $\begin{array}{c}\text { Maximum excavation depth } \\
(\mathrm{m})\end{array}$ & $\begin{array}{c}\text { Buried depth of rock stratum } \\
(\mathrm{m})\end{array}$ & $\begin{array}{c}\text { Length } \\
(\mathrm{m})\end{array}$ & $\begin{array}{c}\text { Width } \\
(\mathrm{m})\end{array}$ & $\begin{array}{c}\text { Main support } \\
\text { structure }\end{array}$ \\
\hline $\begin{array}{l}\text { Gongye South Road } \\
\text { station }\end{array}$ & 17.5 & $9 \sim 18$ & 229.0 & 21.7 & End-suspended pile \\
\hline
\end{tabular}

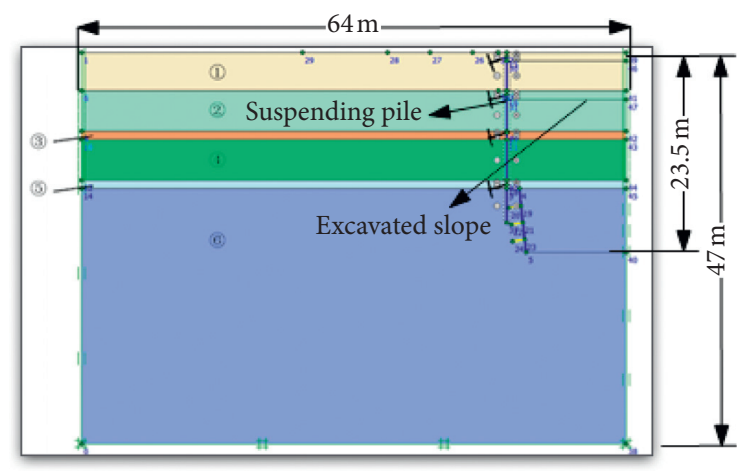

Figure 1: Finite element model of foundation pit supported by suspended foot piles.

Table 2: Physical and mechanical parameters of rock and soil.

\begin{tabular}{|c|c|c|c|c|c|c|}
\hline Soil quality & $\begin{array}{c}\text { Natural heavy " } \gamma \text { " } \\
\left(\mathrm{kN} / \mathrm{m}^{3}\right)\end{array}$ & $\begin{array}{c}\text { Elastic modulus } E \\
(\mathrm{MPa})\end{array}$ & $\begin{array}{c}\text { Poisson's } \\
\text { ratio }\end{array}$ & $\begin{array}{c}\text { Internal friction } \\
\text { angle } \varphi\left({ }^{\circ}\right)\end{array}$ & $\begin{array}{c}\text { Cohesion } c \\
(\mathrm{kPa})\end{array}$ & $\begin{array}{c}\text { Dilatancy angle } \\
\psi\left({ }^{\circ}\right)\end{array}$ \\
\hline (1) Miscellaneous fill & 19.4 & 10 & 0.28 & 10 & 20 & 0 \\
\hline (2) Crushed stone & 20.8 & 35 & 0.30 & 35 & 5 & 5 \\
\hline (3) Silty clay & 18.5 & 13 & 0.32 & 15 & 36 & 0 \\
\hline (4) Crushed stone & 19.2 & 40 & 0.30 & 35 & 5 & 5 \\
\hline $\begin{array}{l}\text { (5) Strongly weathered } \\
\text { mudstone }\end{array}$ & 27.0 & 450 & 0.30 & 23 & 90 & 0 \\
\hline $\begin{array}{l}\text { (6) Moderately weathered } \\
\text { limestone }\end{array}$ & 27.2 & $2.0 \times 103$ & 0.30 & 45 & 300 & 15 \\
\hline
\end{tabular}

TABLE 3: Support structure parameters.

\begin{tabular}{lccccc}
\hline $\begin{array}{l}\text { Supporting } \\
\text { structure }\end{array}$ & $\begin{array}{c}\text { Axial stiffness } \\
(\mathrm{kN})\end{array}$ & $\begin{array}{c}\text { Bending stiffness } \\
(\mathrm{kNm})\end{array}$ & $\begin{array}{c}\text { Poisson's } \\
\text { ratio }\end{array}$ & $\begin{array}{c}\text { Ultimate bending moment } \\
(\mathrm{kN} \cdot \mathrm{m})\end{array}$ & $\begin{array}{c}\text { Ultimate pull } \\
(\mathrm{kN})\end{array}$ \\
\hline Retaining pile & $1.908 \times 10^{7}$ & $6.435 \times 10^{5}$ & 0.2 & 573.5 & - \\
Sprayed concrete & $2.550 \times 10^{6}$ & 2125 & 0.2 & 37.70 & - \\
Rock soil nailing & $1.239 \times 10^{5}$ & - & - & - & 120 \\
\hline
\end{tabular}

\section{Deformation Characteristics of Typical Section of the Foundation Pit Supported by End-Suspended Piles}

3.1. Prestress. Five different prestressing conditions are considered in the model. The original design condition is $1 P$, the other conditions are $0.5 P, 0.75 P, 1.25 P$, and $1.5 P$, respectively $(P$ is the original design prestress value of each bolt), and the other conditions are the same.

The surface settlement outside the pit under various prestress conditions is shown in Figure 6. The influence range of the working condition is about $1.02 \mathrm{H}, 0.85 \mathrm{H}, 0.81 \mathrm{H}$, $0.43 H$, and $0.26 H$, respectively. It can be seen that the influence range of surface settlement decreases with the increase of prestress. The surface settlement deformation of each working condition is similar to the spoon shape, and the maximum surface settlement occurs about $5 \mathrm{~m}$ away from the edge of the foundation pit. The maximum value of ground settlement under each working condition is shown in Figure 7. It can be seen that the maximum ground settlement is approximately inversely proportional to the prestress.

The horizontal displacement of pile is shown in Figure 8. It can be seen that the prestress of anchor cable has a great influence on the horizontal displacement of pile. With the increase of prestress, the horizontal displacement of the pile decreases rapidly, and even there is a negative displacement outside the foundation pit at the top of the pile. The relationship between the maximum horizontal displacement of pile and prestress is shown in Figure 9. It can be seen that the 
TABle 4: Parameters of prestressed anchor cable.

\begin{tabular}{lcccc}
\hline Prestressed anchor cable & Axial stiffness $(\mathrm{kN})$ & Prestress $(\mathrm{kN})$ & Ultimate pull $(\mathrm{kN})$ & Horizontal inclination $\left(^{\circ}\right)$ \\
\hline The first & $3.651 \times 10^{5}$ & 60 & 63 & 20 \\
The second & $3.651 \times 10^{5}$ & 110 & 171 & 15 \\
The third & $3.651 \times 10^{5}$ & 140 & 250 & 15 \\
The fourth & $3.651 \times 10^{5}$ & - & - & 15 \\
\hline
\end{tabular}

TAble 5: Parameters of prestressed anchor cable.

\begin{tabular}{lcc}
\hline Condition & Excavation depth $(\mathrm{m})$ & Time node \\
\hline Condition 1 & 5.5 & The second anchor construction is completed \\
Condition 2 & 9.0 & The third anchor construction is completed \\
Condition 3 & 16.0 & After excavation, the third anchor construction is completed \\
Condition 4 & 23.5 & Excavate to the bottom of the pit and reinforce the rock shoulder \\
\hline
\end{tabular}

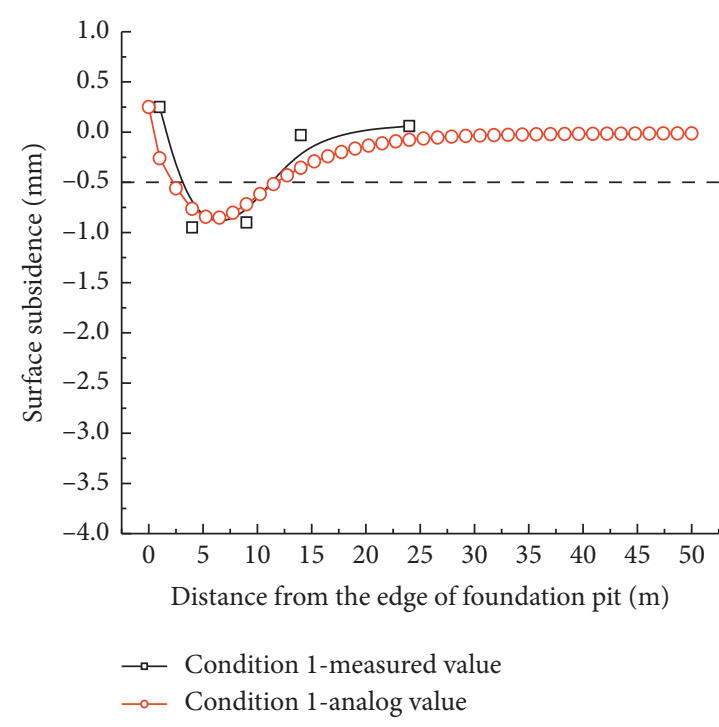

(a)

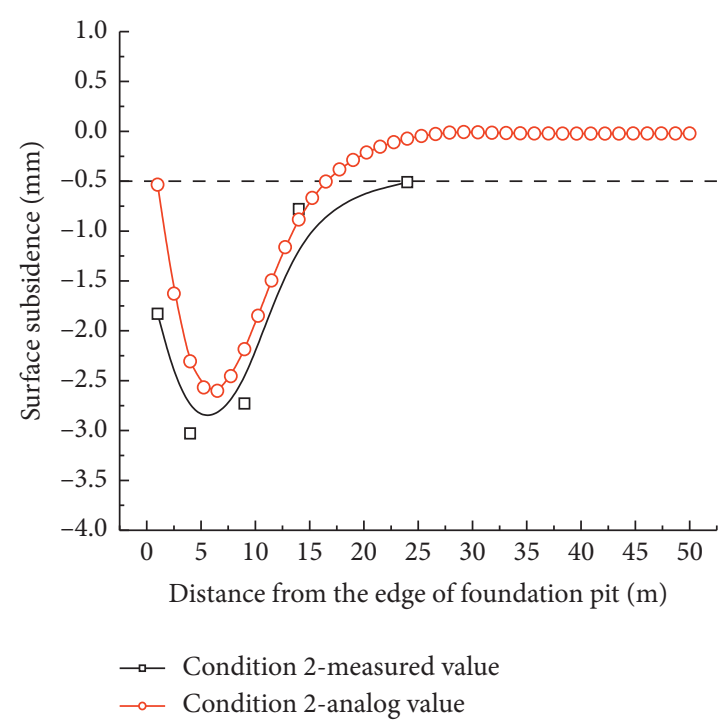

(c)

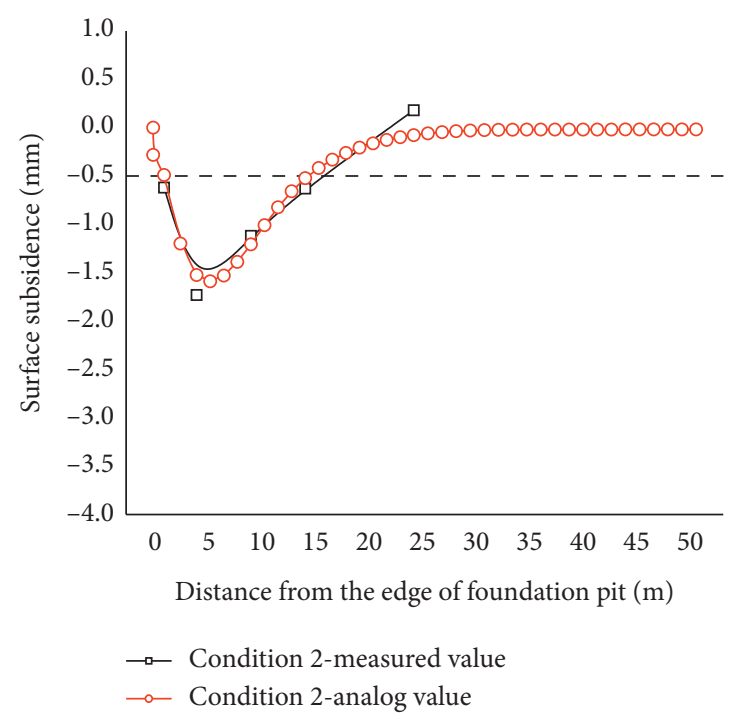

(b)

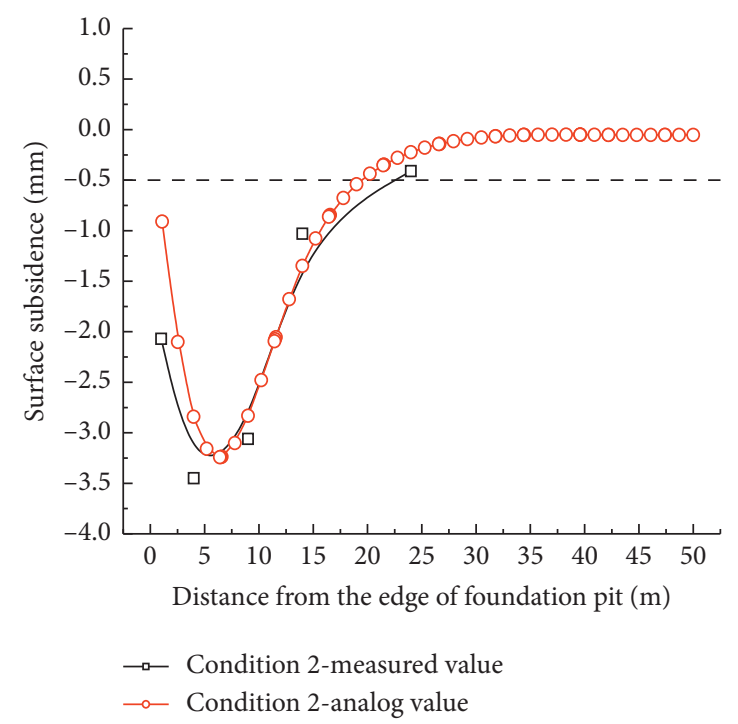

(d)

FIgURe 2: Ground settlement outside the pit under various working conditions. (a) Condition 1. (b) Condition 2. (c) Condition 3. (d) Condition 4. 


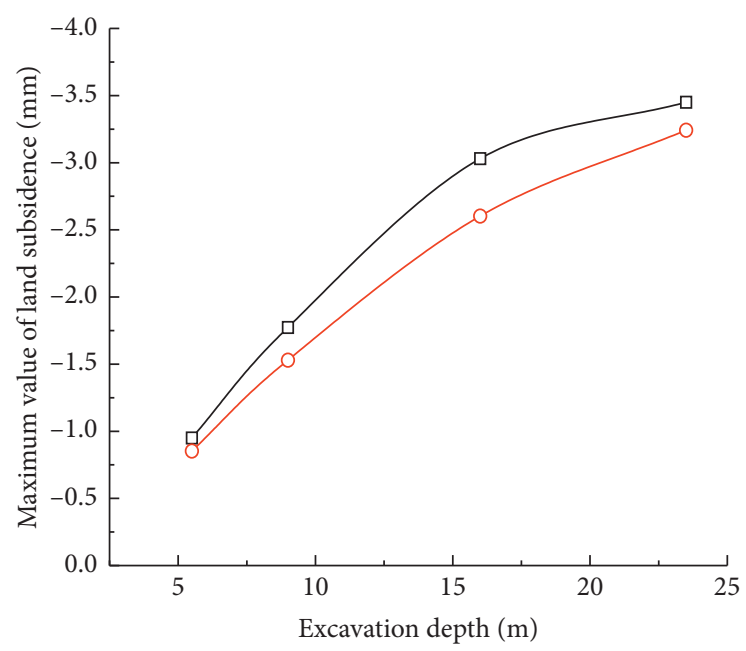

Figure 3: Ground settlement outside the pit under various working conditions.

relationship between the maximum horizontal displacement of pile and prestress is approximately in inverse proportion. The maximum horizontal displacement under $0.5 P$ condition is $76.5 \%$ higher than that under the original design condition $(1 P)$, while the maximum horizontal displacement under $1.5 P$ condition is $44.9 \%$ lower than that under the original design condition $(1 P)$.

The shear force and bending moment of pile body under various working conditions are shown in Figure 10. The influence of prestressed anchor cable on pile stress is mainly reflected in two aspects. One is the effect of direct force; for example, the mutation on the shear diagram reflects the effect of prestress: the greater the prestress is, the greater the mutation is; the other is that the increase of prestress also limits the displacement of the pile, thus indirectly changing the effect of the force between the pile and soil. Above the excavation face $(16 \mathrm{~m})$, the increase of anchor cable prestress makes the pile move out of the foundation pit, which leads to the increase of earth pressure. For example, the shear diagram between the first and second anchor cables and between the third anchor cable and the excavation face show that the earth pressure under $1.5 P$ condition increases rapidly. Below the excavation face, that is, the rock shoulder, the earth pressure of the rock shoulder decreases because the prestressed anchor cable controls the displacement of the pile. In the bending moment diagram, there is a similar trend. The maximum absolute values of pile shear force and bending moment are $233.2 \mathrm{kN}$ and $355.7 \mathrm{kN} \cdot \mathrm{m}$ under $0.5 P$ condition, which are $9.2 \%$ and $32.1 \%$ higher than the original design condition $(1 P)$.

3.2. Shoulder Width. Five different shoulder widths are considered in the model. In the original design, the width of rock shoulder is $1.5 \mathrm{~m}$, while in other working conditions, the width of rock shoulder is $0.5 \mathrm{~m}, 1.0 \mathrm{~m}, 2.0 \mathrm{~m}$, and $3.0 \mathrm{~m}$, respectively.

The surface settlement under different shoulder widths is shown in Figure 11. It can be seen that the width of rock shoulder has little influence on surface subsidence, and the influence range of surface subsidence is about $0.66 \mathrm{~h} \sim 0.82 \mathrm{~h}$. This is due to the change of the width of the rock shoulder to strengthen or weaken the constraint at the bottom of the end-suspended pile.

The maximum value of ground settlement under each working condition is shown in Figure 12. It can be found that the maximum value of ground settlement changes relatively fast from $0.5 \mathrm{~m}$ to $1.5 \mathrm{~m}$ of rock-shoulder width, and the change speed is slightly slow when it is greater than $1.5 \mathrm{~m}$, but the total change range is not large. Compared with the original design condition $(1.5 \mathrm{~m})$, the width of rock shoulder of $0.5 \mathrm{~m}$ is increased by about $14.4 \%$, while the width of rock shoulder of $3 \mathrm{~m}$ is only reduced by $7.1 \%$.

The horizontal displacement of pile is shown in Figure 13. It can be seen that the influence of rock-shoulder width on the horizontal displacement of pile is mainly below $10 \mathrm{~m}$, and the larger the rock-shoulder width is, the smaller the horizontal displacement of pile is. This is mainly due to the increase of the thickness of the rock shoulder, which makes the ability of restraining the horizontal displacement of the pile increase. And it can be found that the deformation curve of the pile is close to the deformation curve of the rock-socketed part of the rock-socketed pile when the width of the rock shoulder is $3 \mathrm{~m}$, which indicates that there is a marginal effect in increasing the width of the rock shoulder to control the horizontal displacement of the pile, and the main reason is that there is a free face in the rock shoulder of the end-suspended pile.

The relationship between the maximum horizontal displacement and the width of rock shoulder is shown in Figure 14. It can be found that the maximum horizontal displacement of the pile changes relatively quickly from $0.5 \mathrm{~m}$ to $1.5 \mathrm{~m}$ of the width of rock shoulder. Compared with the original design condition, the $0.5 \mathrm{~m}$ width of rock shoulder increases about $18.6 \%$, while the $3 \mathrm{~m}$ width of rock shoulder decreases only $8.9 \%$.

The shear force and bending moment of pile body under various working conditions are shown in Figure 15. The maximum absolute values of pile shear force and bending moment are $222.9 \mathrm{kN}$ and $338.8 \mathrm{kN} \cdot \mathrm{m}$, respectively, which 


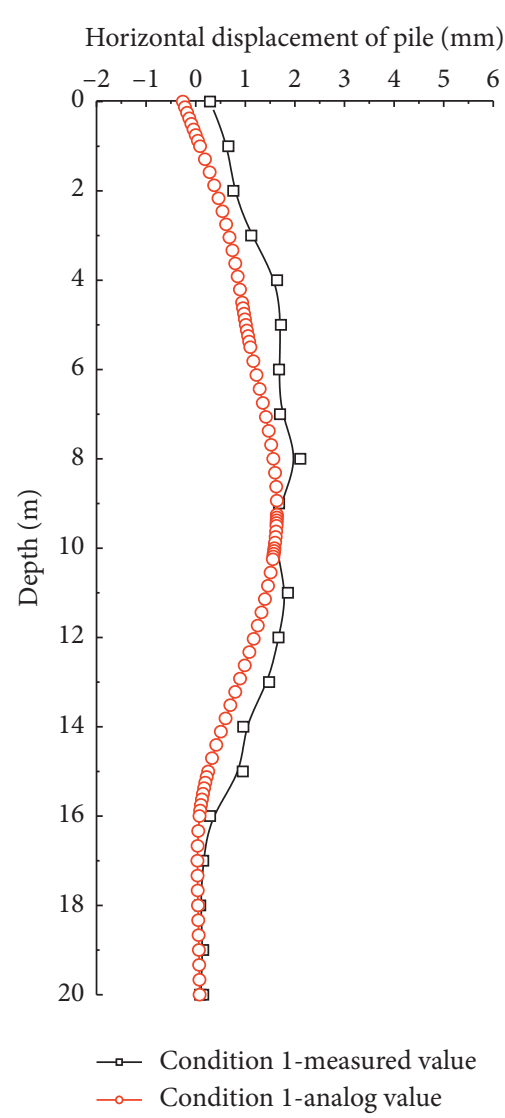

(a)

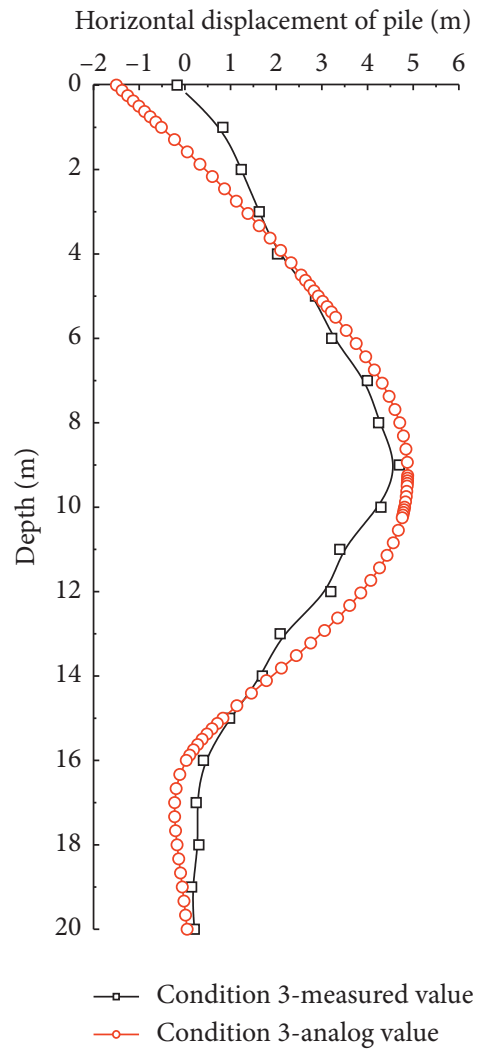

(c)
Horizontal displacement of pile ( $\mathrm{mm})$

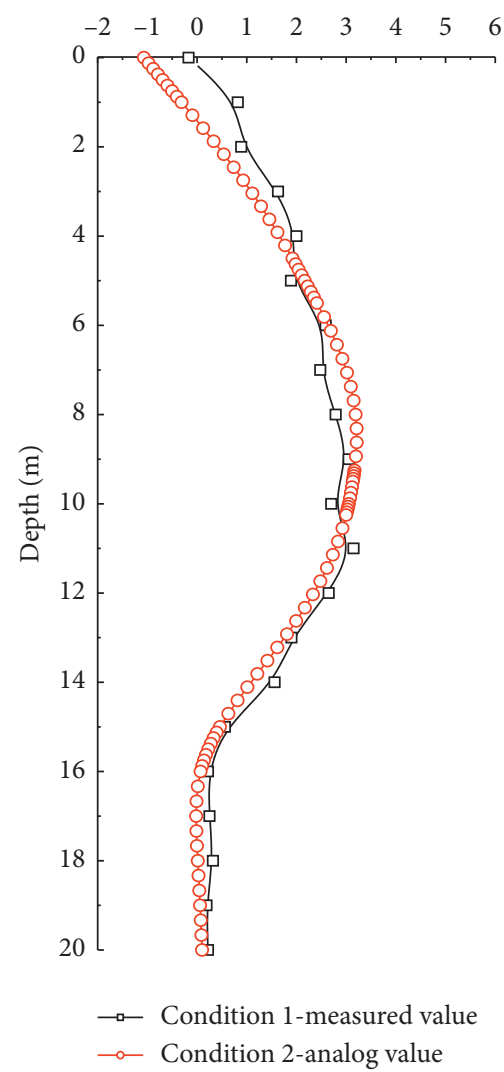

(b)

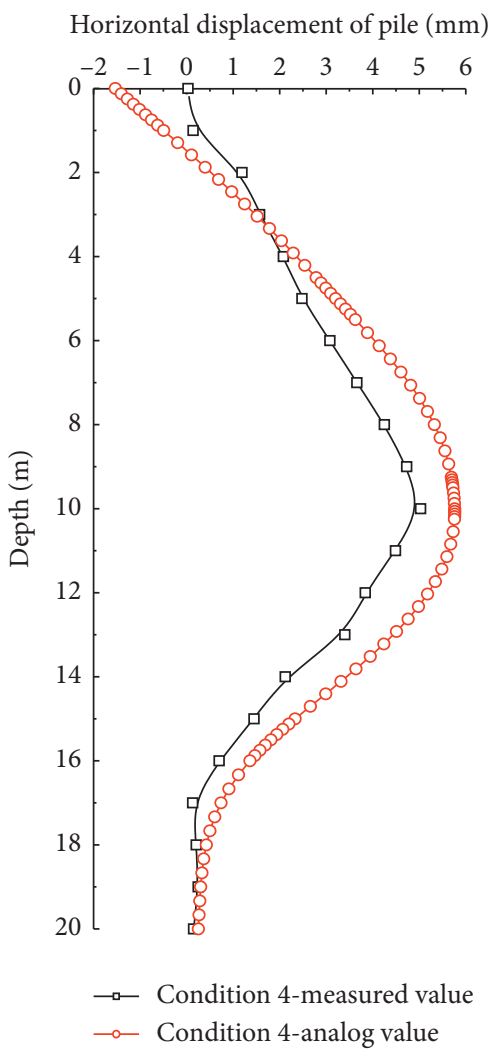

(d)

Figure 4: Horizontal displacement of pile under different working conditions. (a) Condition 1. (b) Condition 2. (c) Condition 3. (d) Condition 4. 


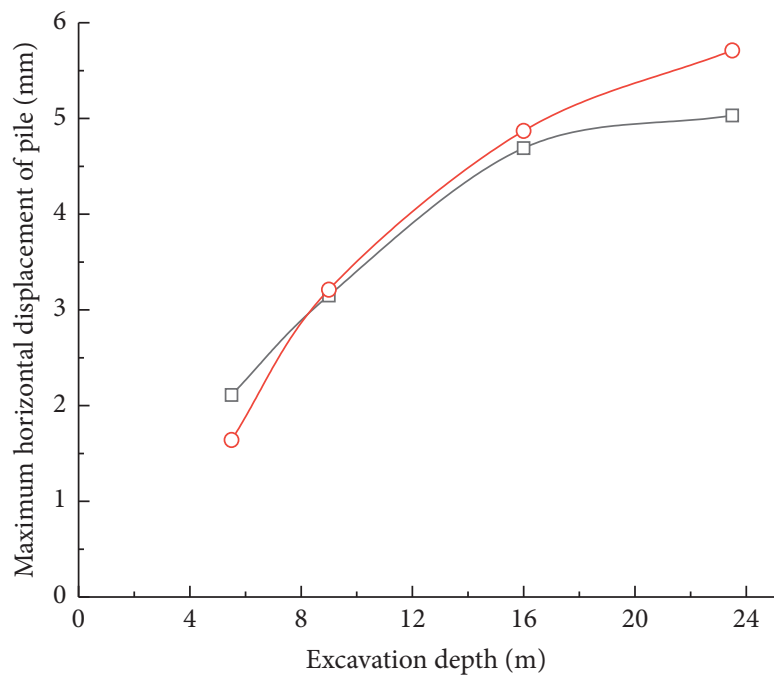

$\rightarrow$ Measured value

$\because$ Analog value

FIGURE 5: The relationship between maximum horizontal displacement of the pile and excavation depth.

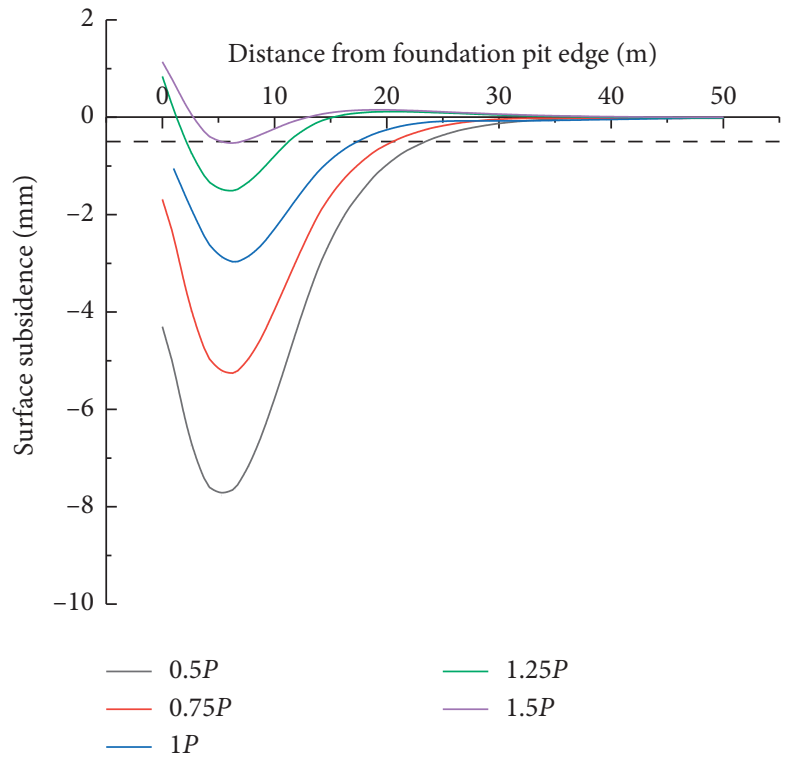

FIgURE 6: Surface subsidence outside the pit.

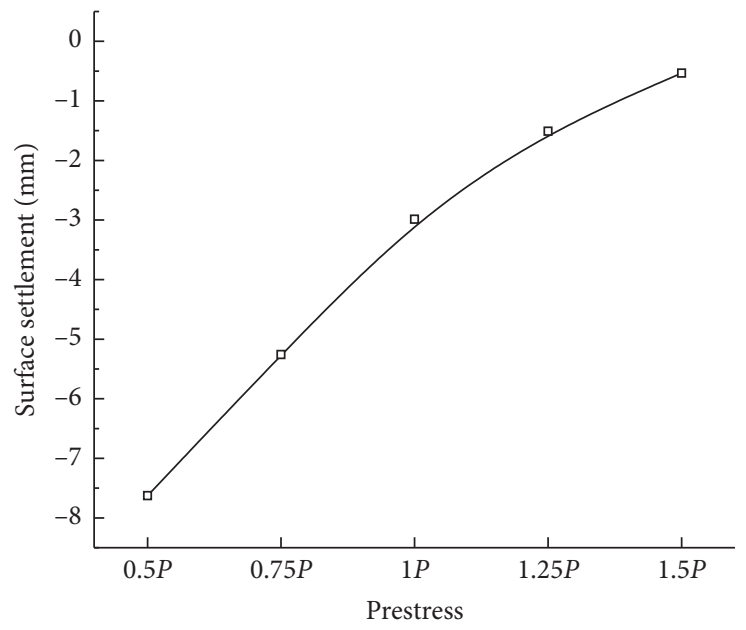

FIGURE 7: Influence of prestress on maximum ground settlement. 


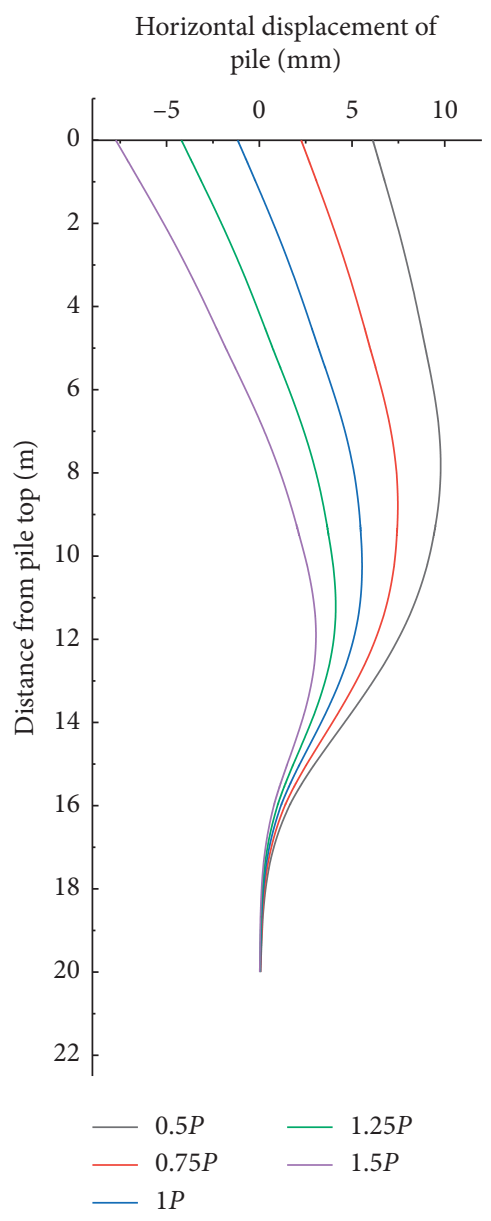

FIGURE 8: Horizontal displacement of the pile.

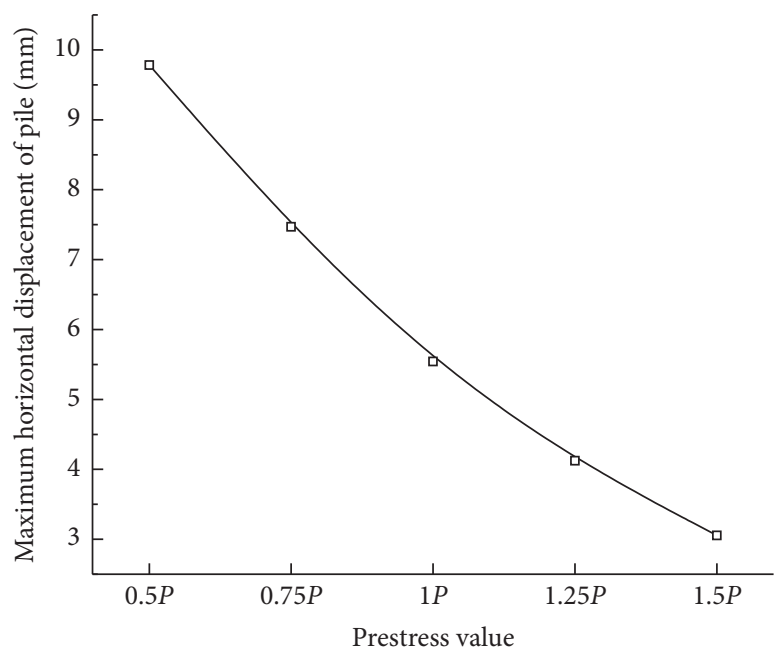

FIGURE 9: Influence of prestress on maximum horizontal displacement of the pile.

are increased by $4.9 \%$ and $29.7 \%$ compared with the original design condition. It can also be found that the influence of rock-shoulder width on pile shear and bending moment is mainly concentrated in the part below $10 \mathrm{~m}$, especially the rock-shoulder part. When the rock-shoulder width is $0.5 \mathrm{~m}$ and $1.0 \mathrm{~m}$, the overall shear-force of the rock-shoulder part (below $16 \mathrm{~m}$ ) is small, and the trend is to increase with the increase of depth; with the increase of rock-shoulder width, the shear force value of the pile from $16 \mathrm{~m}$ to $18 \mathrm{~m}$ gradually increases and then decreases gradually; when the rock- 


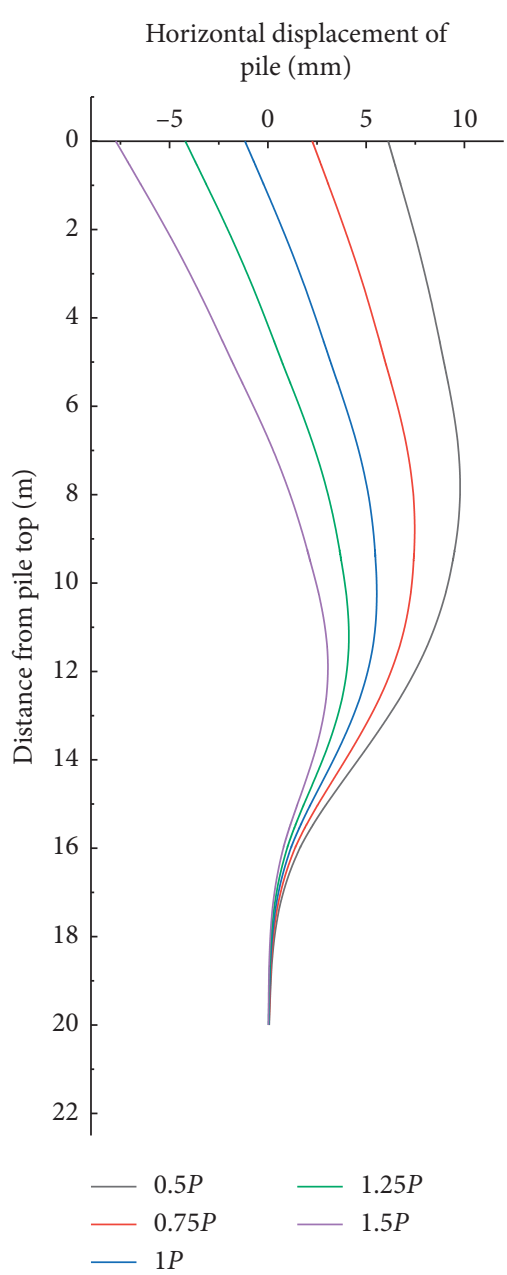

(a)

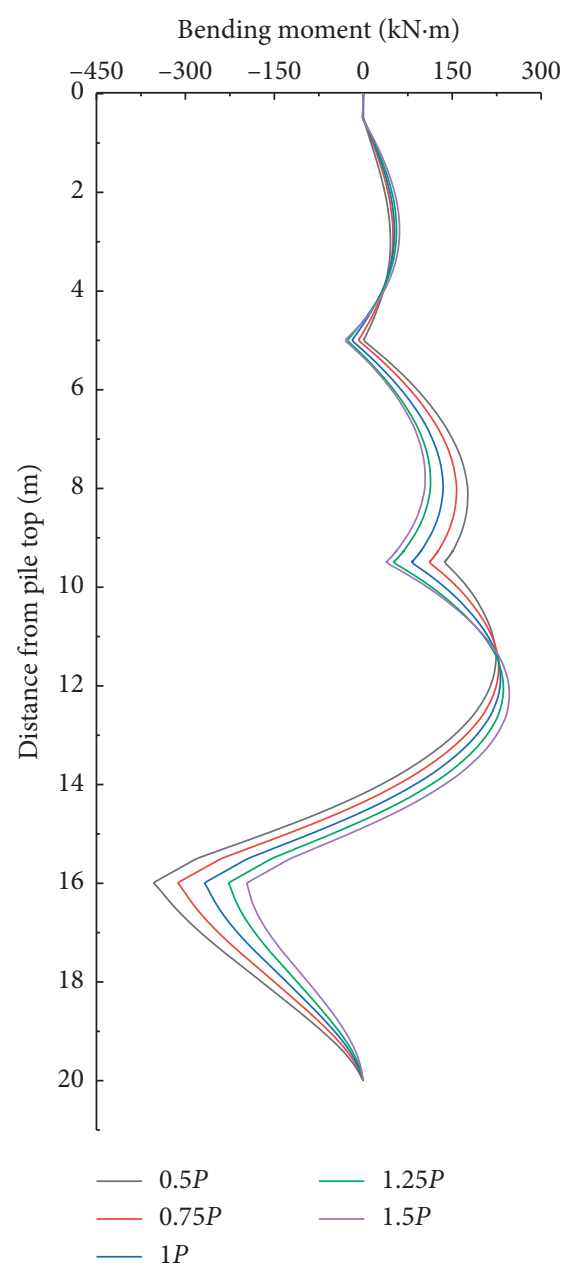

(b)

Figure 10: Pile internal force diagram. (a) Shear diagram. (b) Bending moment diagram.

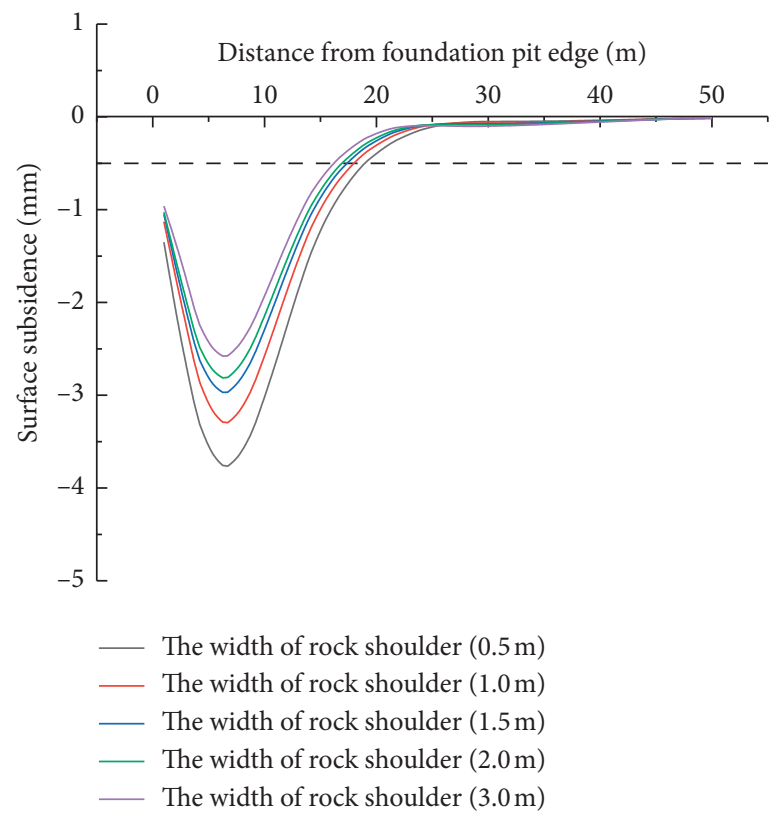

Figure 11: Surface subsidence outside the pit. 


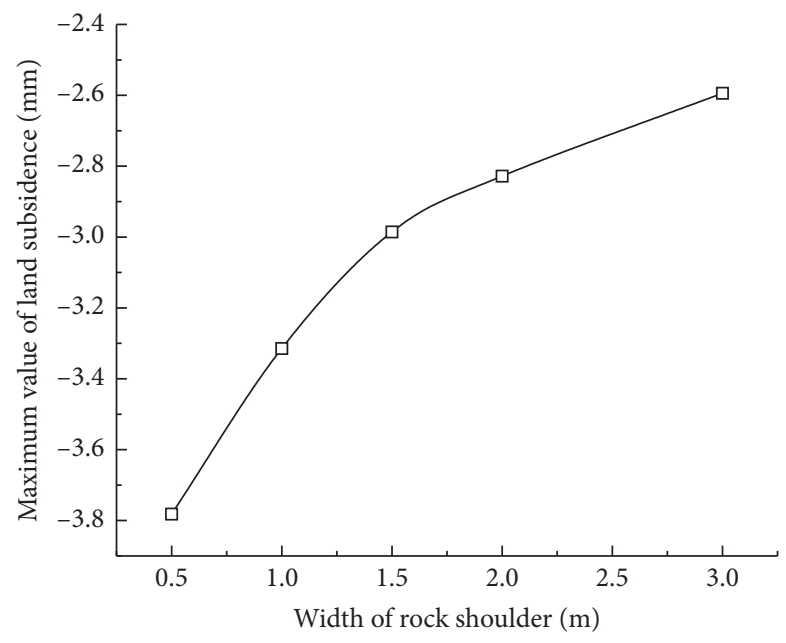

FIGURE 12: Influence of rock-shoulder width on maximum land subsidence.

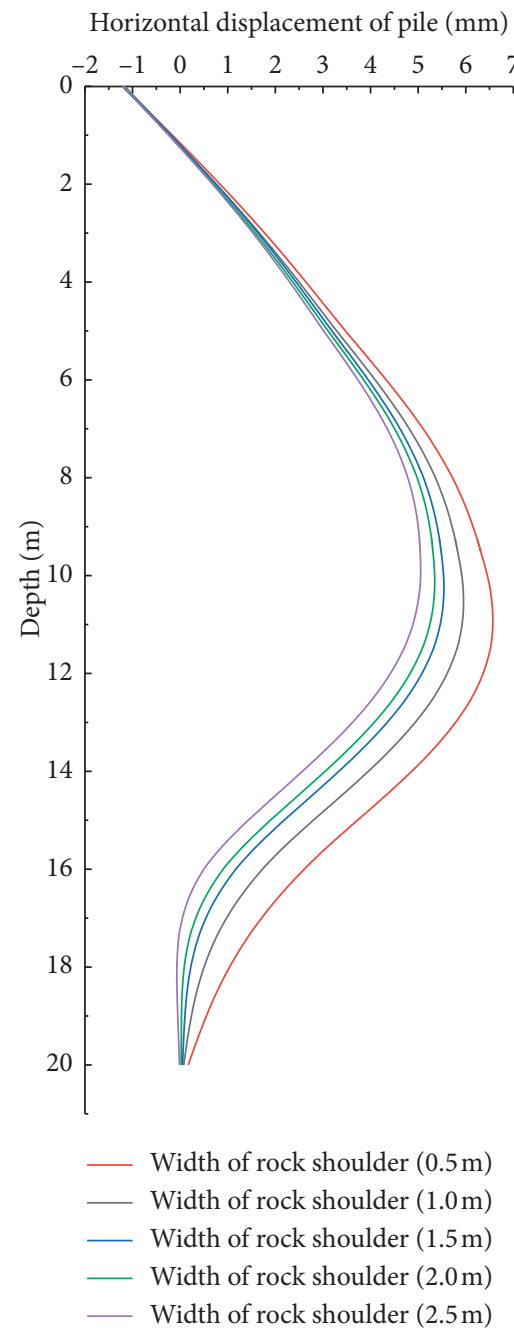

Figure 13: Horizontal displacement of the pile. 


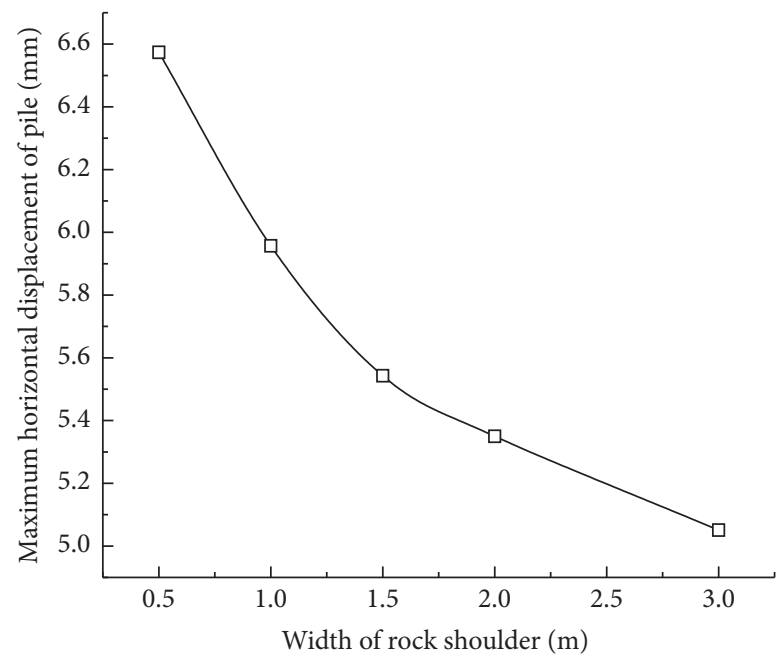

FIGURE 14: Influence of shoulder width on horizontal displacement of the pile.

shoulder width is $3 \mathrm{~m}$, it first increases rapidly and then gradually decreases to 0 . This shows that the stress characteristics of the pile at the shoulder are related to the restraint capacity of the shoulder.

3.3. Rock-Socketed Depth. Five different rock-socketed depth conditions are set in the model. The original design rocksocketed depth is $4 \mathrm{~m}$, and the other working conditions are $1 \mathrm{~m}, 2 \mathrm{~m}, 3 \mathrm{~m}$, and $7 \mathrm{~m}$, respectively.

The surface settlement outside the pit under different rock-socketed depths is shown in Figure 16, which shows that the rock-socketed depth has little effect on the surface settlement, and the influence range of the surface settlement is similar. The maximum value of ground settlement under each working condition is shown in Figure 17. It can be found that the maximum value of ground settlement changes relatively fast from $1 \mathrm{~m}$ to $4 \mathrm{~m}$ rock-socketed depth, and the change speed is slightly slower when it is greater than $4 \mathrm{~m}$, but the total change range is not large. Compared with the original design condition $(4 \mathrm{~m})$, the rock-socketed depth of $1 \mathrm{~m}$ increases by about $21.8 \%$, while the rock-socketed depth of $3 \mathrm{~m}$ decreases by only $2.4 \%$.

The horizontal displacement of the pile is shown in Figure 18. It can be seen that when the rock-socketed depth is less than $4 \mathrm{~m}$, the smaller the rock-socketed depth is, the greater the displacement of the pile is. However, the pile deformation curves of $4 \mathrm{~m}$ and $7 \mathrm{~m}$ rock-socketed depth are almost overlapped, which indicates that increasing the rocksocketed depth after $4 \mathrm{~m}$ has little effect on the horizontal displacement of pile, and increasing the rock-socketed depth to control the horizontal displacement of pile also has marginal effect.

The relationship between the maximum horizontal displacement and the rock-socketed depth is shown in Figure 19. It can be found that the maximum horizontal displacement of the pile changes relatively quickly from $1 \mathrm{~m}$ to $4 \mathrm{~m}$ rock-socketed depth. Compared with the original design condition $(4 \mathrm{~m})$, the $1 \mathrm{~m}$ rock-socketed depth condition increases by $16.7 \%$, while the $7 \mathrm{~m}$ rock-socketed depth condition decreases by $0.31 \%$.

The shear force and bending moment of pile body under various working conditions are shown in Figure 20. It can be found that the difference of pile shear force above the rock shoulder is not big, while the shear force below the rock shoulder decreases with the increase of rock-socketed depth. This shows that the smaller the rock-socketed depth is, the more the strength of rock shoulder that can be exerted, and the corresponding maximum horizontal displacement of pile increases; there is no significant difference in pile shear force between $4 \mathrm{~m}$ and $7 \mathrm{~m}$ rock-socketed depth.

3.4. Optimization Design [9-12]. Based on the analysis of the above influencing factors, the following optimization design suggestions are put forward for the supporting scheme design of end-suspended piles:

(1) There is a boundary effect on the rock-socketed depth. Under the geological conditions of this paper, the reasonable rock-socketed depth is about $3 \mathrm{~m} \sim 4 \mathrm{~m}$; that is, the embedding ratio is about $0.158 \sim 0.200$, and the rock-socketed depth range of end-suspended piles can be reasonably adjusted according to the rock strength and other properties.

(2) The prestress of anchor cable can effectively slow down the ground settlement, pile stress, and deformation. In this regard, the greater the prestress, the better. However, the excessive prestress of the anchor cable in the upper part of the end-suspended piles will lead to the displacement of the upper part of the pile to the outside of the foundation pit and even lead to the active destruction of the soil behind the pile. Therefore, it needs to be considered comprehensively in combination with the engineering geology and on-site construction conditions. Under the geological conditions of this paper, it can be set as $1 P \sim 1.25 P$. 


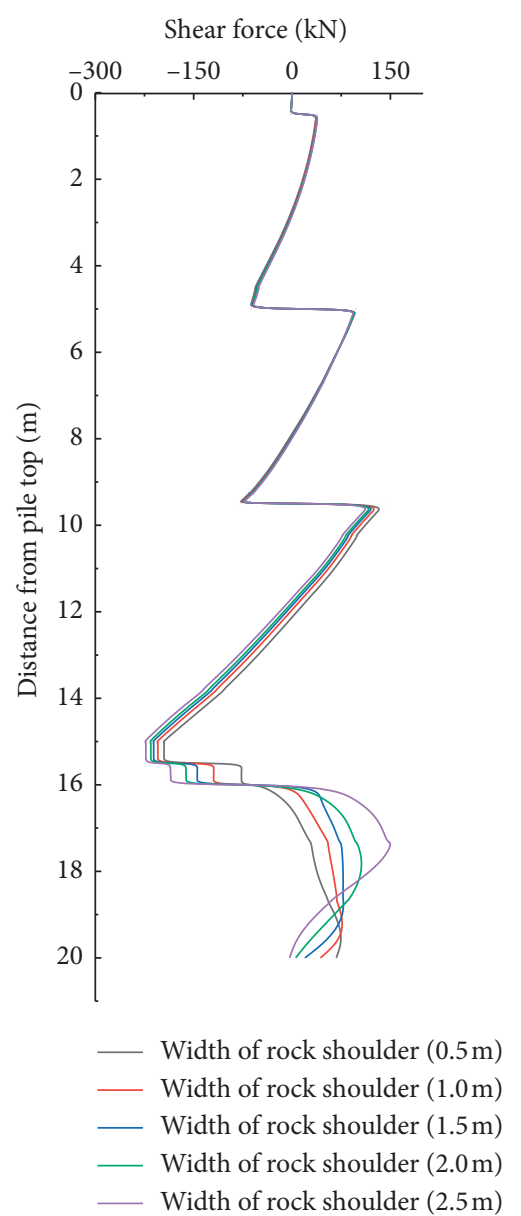

(a)

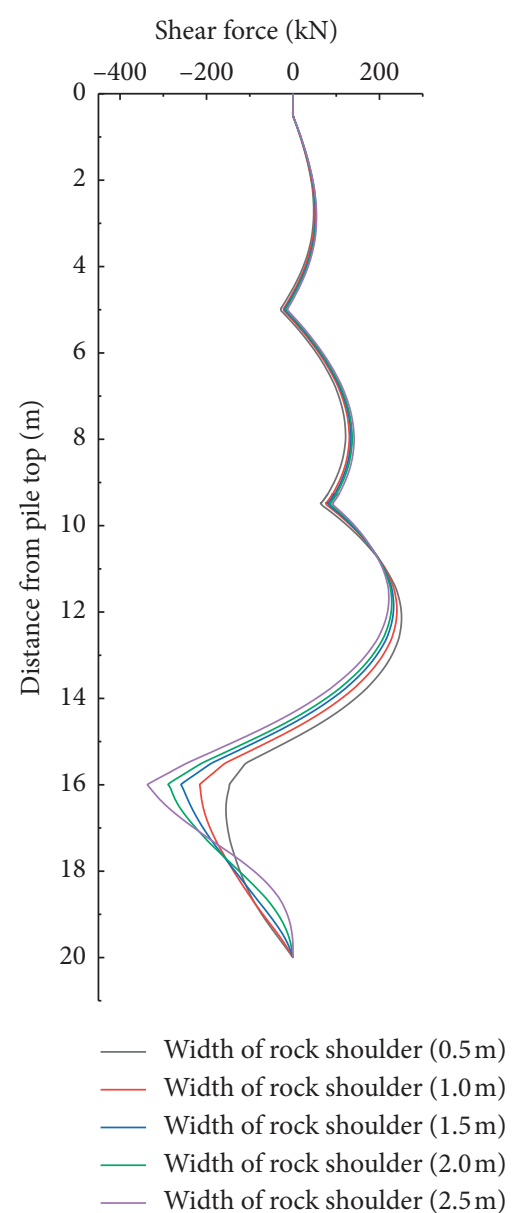

(b)

Figure 15: Pile internal force diagram. (a) Shear diagram. (b) Bending moment diagram.

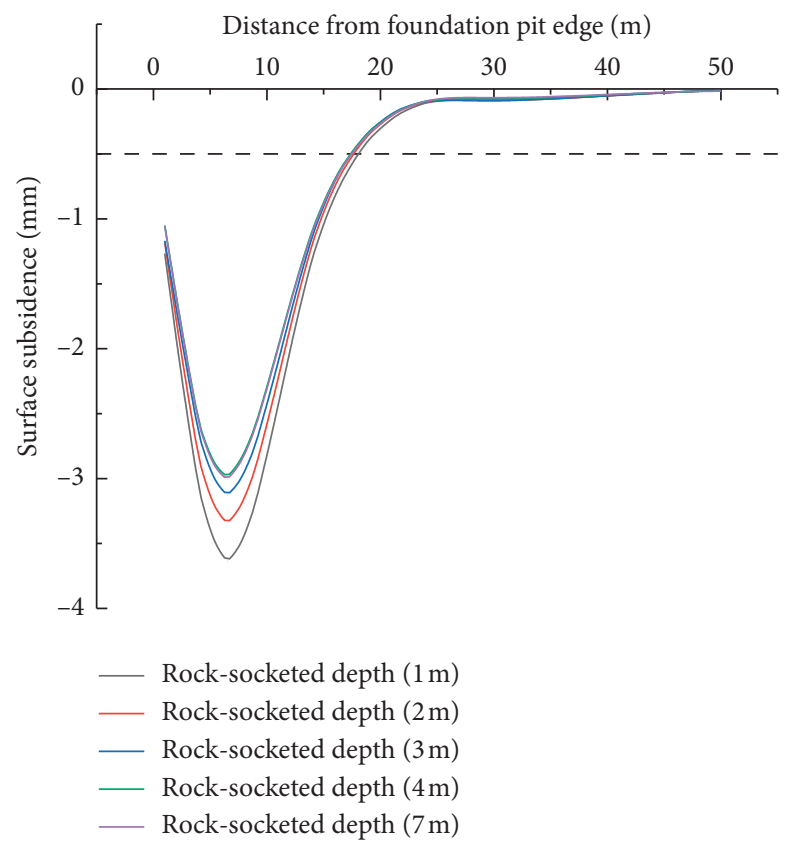

Figure 16: Surface subsidence outside the pit. 


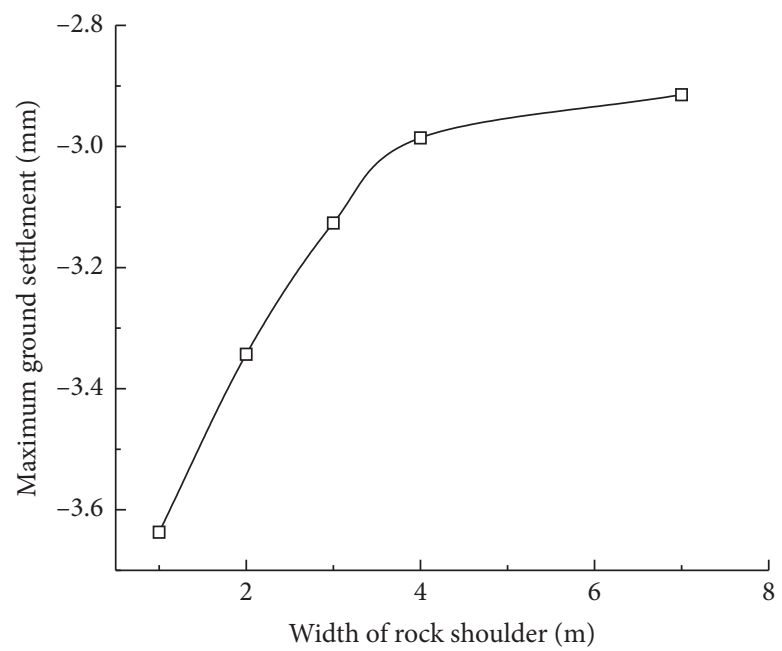

FIgURE 17: Influence of rock-socketed depth on maximum land subsidence.

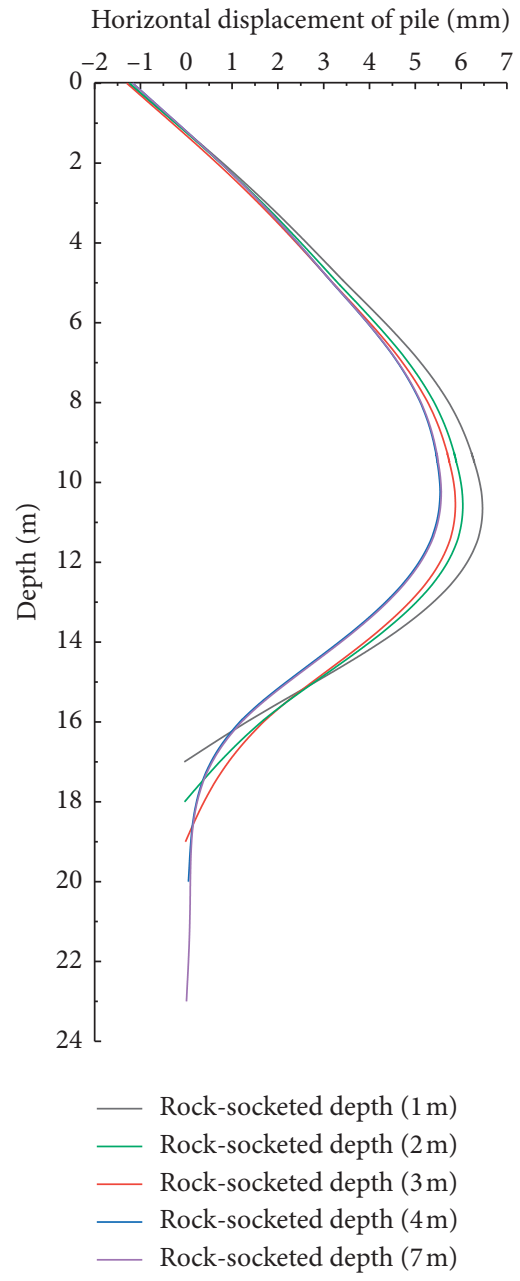

FIGURE 18: Horizontal displacement of the pile.

(3) The width of reserved rock shoulder is one of the key factors to control the stability of end-suspended piles. However, increasing the width of rock shoulder will increase the bending moment and shear-force of end-suspended piles, increase the cost of pile, and increase the excavation amount of foundation pit. At the same time, considering that the influence of rock shoulder width on ground settlement and pile 


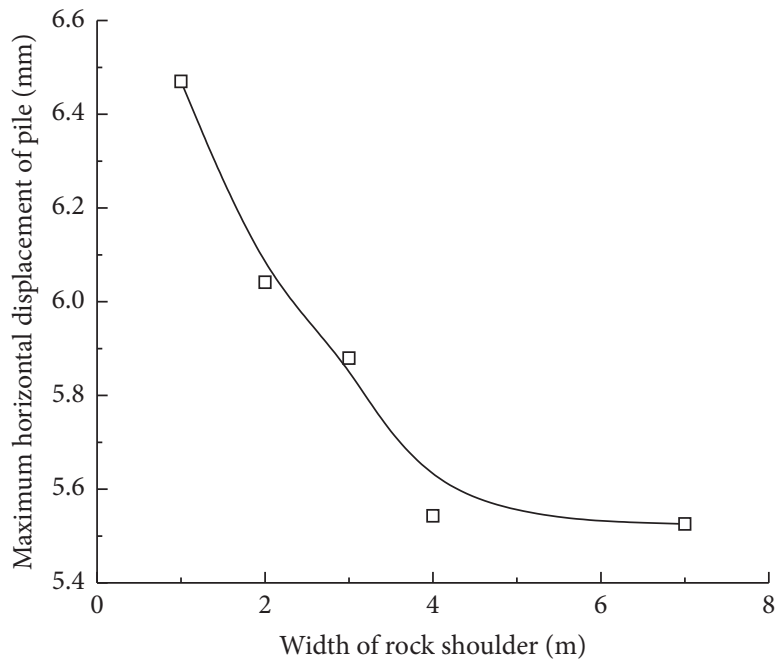

FIGURE 19: Influence of rock-socketed depth on horizontal displacement of the pile.

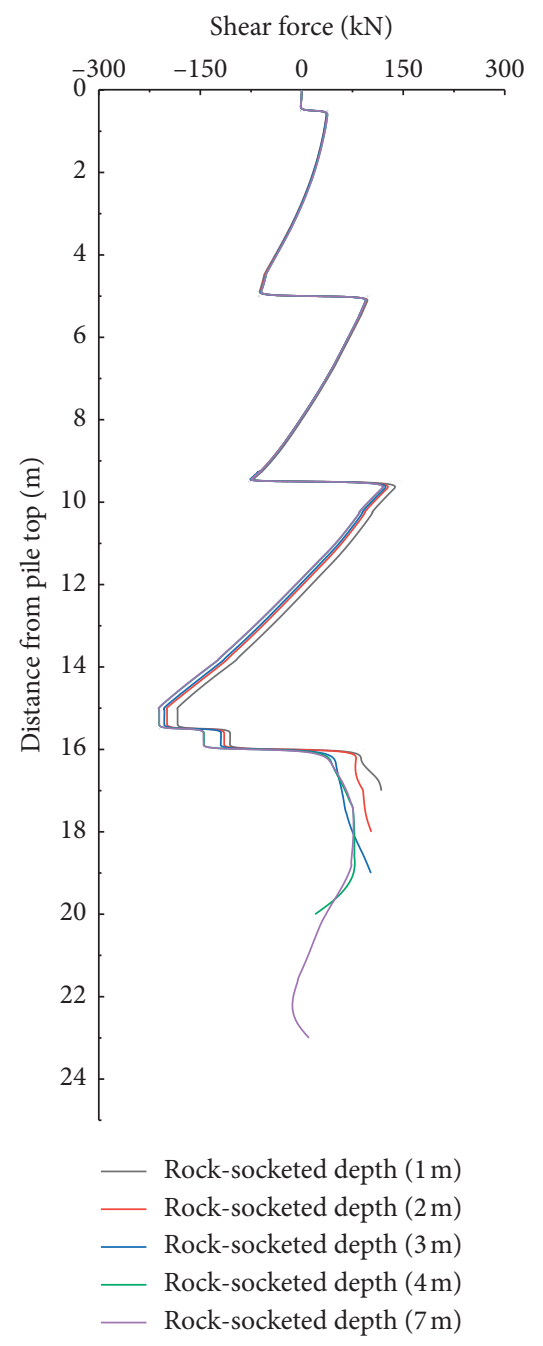

(a)

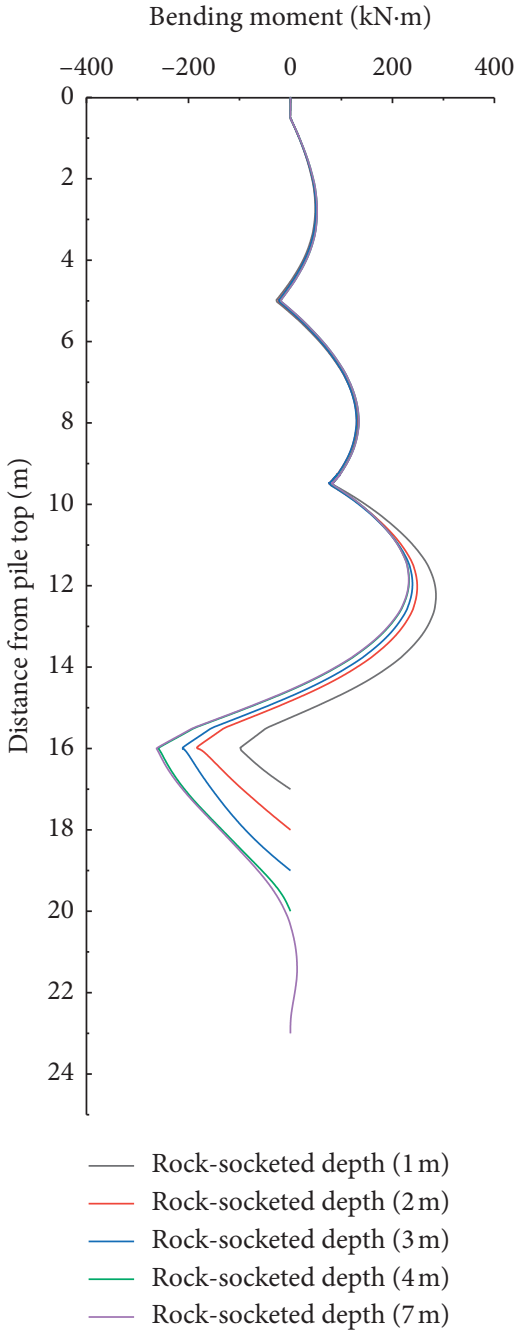

(b)

Figure 20: Pile internal force diagram. (a) Shear diagram. (b) Bending moment diagram. 
horizontal displacement is relatively small, it is suggested to reserve rock shoulder width in the range of $1.0 \sim 1.5 \mathrm{~m}$ under the site conditions.

\section{Conclusions}

In this paper, the mechanical and deformation characteristics of the supporting structure of end-suspended piles in Jinan area are studied. On the basis of the measured data, the finite element model is established by two-dimensional numerical simulation method, and the stress and deformation characteristics of the support are analyzed. Combined with the relevant simulation data, the following conclusions and suggestions are obtained:

(1) Most of the ground settlement and pile horizontal displacement outside the foundation pit of the soil rock combination supported by the end-suspended pile occur in the soil excavation stage.

(2) The results show that the prestress of anchor cable has the most significant effect on the ground settlement outside the pit, the pile shear force and bending moment decrease with the increase of anchor cable prestress, and the pile shear force and bending moment increase with the increase of rockshoulder width.

(3) There is a boundary effect on the rock-socketed depth. Under the geological conditions of this paper, the reasonable embedding ratio is about 0.158 0.200.

(4) The prestressed anchor cable can effectively reduce the ground settlement, pile stress, and deformation. Under the geological conditions of this paper, it can be set as $1 P \sim 1.25 P$.

(5) The width of rock shoulder has little influence on the ground settlement and the horizontal displacement of the pile. The larger the width of rock shoulder is, the greater the shear force and bending moment of the pile are. Therefore, it is suggested that the width of reserved shoulder should be selected in the range of $1.0 \mathrm{~m} \sim 1.5 \mathrm{~m}$ under the geological conditions.

\section{Data Availability}

No data were used to support this study.

\section{Conflicts of Interest}

The authors declare that there are no conflicts of interest regarding the publication of this paper.

\section{References}

[1] X. J. Tong, A. H. Cheng, G. Z. Fan et al., "Study of standard stratum division in Jinan urban area," Urban Geotechnical Investigation \& Surveying, vol. 165, no. 2, pp. 165-171, 2016.

[2] H. J. Liu and B. Li, "Analysis of supporting mechanism of micro-steel-pipe piles in rock foundation pit," Rock and Soil Mechanics, vol. 33, no. supp. 1, pp. 217-222, 2012.

[3] H. J. Liu, D. Li, T. Sun et al., "Numerical analysis on design of dualistic foundation pit with 'end-suspended pile," Journal of
Civil, Architectural \&Environmental Engineering, vol. 31, no. 5, pp. 42-43, 2013.

[4] J. Wu, Y. Z. Yang, S. M. Liao et al., "Mechanical analysis and design optimization of end-suspended piles of deep foundation pit in soil-rock composite strata," Tunnel Construction, vol. 38, no. 2, pp. 80-86, 2018.

[5] B. P. Abbott, R. Abbott, T. D. Abbott et al., "Observation of gravitational waves from a binary black hole merger," Physical Review Letters, vol. 116, no. 6, Article ID 061102, 2016.

[6] H. G. Tian, "Case study on design optimization of end-suspended piles of foundation pit of a cut-and-cover metro station in soilrock combined strata," Tunnel Construction, vol. 35, no. 7, pp. 635-641, 2015.

[7] Y. H. Zhuang, L. F. Feng, L. Ge et al., "Analysis on application of deep excavation with composite soil nailing wall in soilrock dualistic structure ground," Guangdong Architecture Civil Engineering, vol. 35, no. 7, pp. 14-17, 2015.

[8] Z. H. Zhu, T. Liu, H. X. Shan et al., "Study of supporting type for deep foundation pit in areas of rock and soil," Guangdong Architecture Civil Engineering, vol. 32, no. supp. 1, pp. 619623, 2011.

[9] R. B. Peck, "Deep excavation and tunneling in soft ground," in Proceedings of the 7th International Conference on Soil Mechanics and Foundation Engineering, pp. 225-290, Mexico city, MX, USA, August 1969.

[10] Q. H. Liu, "Analysis on deformation characteristics of deep foundation pit of metro station in Changzhou area," Rock and Soil Mechanics, vol. 32, no. 1, pp. 120-125, 2019.

[11] S. Li, D. L. Zhang, Q. Fang et al., "Research on characteristics of ground surface deformation during deep excavation in Beijing subway," Chinese Journal of Rock Mechanics and Engineering, vol. 31, no. 1, pp. 189-198, 2012.

[12] H. J. Liu, G. C. Zhang, T. Liu et al., "Monitoring and analysis of deformation of foundation pits in strata with rock-soil combination," Chinese Journal of Geotechnical Engineering, vol. 32, no. supp. 2, pp. 550-553, 2010. 